ISSN: $1896-4087$

DOI: http://dx.doi.org/10.21784/ZC.2018.020

MATEUSZ K. MACIEJCZUK, KONRAD WNOROWSKI

Uniwersytet w Białymstoku

MATEUSZ OLCHANOWSKI

Uniwersytet w Białymstoku/Izba Adwokacka w Białymstoku

\title{
Cyberprzestrzeń a bezpieczeństwo dzieci w świetle rozwiązań Organizacji Narodów Zjednoczonych oraz Rady Europy
}

\author{
Cyberspace and child safety in the light of the solutions \\ of the United Nations and the Council of Europe
}

\begin{abstract}
Streszczenie:
Niniejszy artykuł stanowi początek rozważań na temat bezpieczeństwa dzieci w cyberprzestrzeni. W pierwszej kolejności rozważania poświęcone zostały pojęciu używanym w tytule, tj. „bezpieczeństwo”, „dzieci” oraz „cyberprzestrzeń”. W związku $\mathrm{z}$ brakiem jednolitych definicji legalnych wyżej wymienionych terminów dokonano analizy aktów prawnych oraz doktryny w tym zakresie. W dalszej kolejności przedstawiono korelację pomiędzy cyberbezpieczeństwem dzieci oraz prawem i stawianymi, w tym kontekście, przed nim zadaniami. Kolejnym elementem analizy stały się osiągnięcia Organizacji Narodów Zjednoczonych oraz Rady Europy dotyczące bezpieczeństwa dzieci w cyberprzestrzeni. Warto podkreślić, iż autorzy starali się wskazać na ewolucję pojmowania zagadnienia oraz efekty podejmowanych działań w sferach: prawnej i faktycznej. Przy każdej okazji wskazywano na skutki poszczególnych aktywności ONZ oraz Rady Europy.
\end{abstract}

Słowa kluczowe: bezpieczeństwo, dzieci, cyberprzestrzeń, cyberbezpieczeństwo 
Mateusz K. Maciejczuk et al. - Cyberprzestępczość a bezpieczeństwo...

\begin{abstract}
:
This article launches a reflection on children safety in cyberspace. In the first place, consideration is given to the concept used in the title, i.e. 'security', 'children' and 'cyberspace'. Owing to the absence of any uniform definitions of the legal terms mentioned above, legal acts and doctrines in this area have been analyzed. Next, the correlation between the child cyber security-- the law and its challenges has been presented. Another element of the analysis is the achievements of the United Nations and the Council of Europe on the safety of children in cyberspace. It is worth to emphasize that the authors tried to point out the evolution of the understanding of the issue and the effects of the actions taken in the legal and factual spheres. On each occasion the effects of particular activities of the UN and the Council of Europe were pointed out.
\end{abstract}

Keywords: security, children, cyberspace, cyber security

\title{
Wprowadzenie
}

Procesy zachodzące we współczesnym świecie związane są niemal ze wszystkimi dziedzinami ludzkiej aktywności. W sferze podmiotowej skutki tych przemian odczuwa przede wszystkim poszczególny człowiek niezależnie od miejsca zamieszkania, statusu materialnego oraz innych personalizujących cech. Warto podkreślić, że bardzo często jego woli nie jest potrzebne. W sferze przedmiotowej warto wskazać na procesy globalizacyjne oraz rewolucję technologiczną, które na stałe zmieniają utrwalony porządek funkcjonowania jednostek, społeczeństw i państw, co ma wpływ na całą międzynarodową społeczność1. Szczególną rolę w kreowaniu ww. zmian odgrywa pojawienie się komputerów tworzących sieć, co musiało spowodować, jak twierdzi Manuel Castells, historyczną zmianę, bowiem „gdy tylko nowe techniki informacyjne rozprzestrzeniły się i zostały przejęte przez różne kraje, różne kultury, różnorodne organizacje i rozmaite cele, nastąpiła eksplozja różnego rodzaju zachowań i użytków, co zwrotnie przyczyniło się do powstania technologicznych innowacji, przyspieszając tempo i rozszerzając zasięg technologicznej zmiany, a także

\footnotetext{
1 T. R. Aleksandrowicz, Świat w sieci. Państwa, społeczeństwa, ludzie. W poszukiwaniu nowego paradygmatu bezpieczeństwa narodowego, Warszawa 2014, s. 9.
} 
różnicując jej źródła”2. Powyższe zatem można traktować jako poważny argument za podtrzymywaniem trwającego dyskursu o roli prawa w kontekście ww. zjawisk, które mogą nieść w swym inwentarzu wiele zagrożeń. $W$ sferze podmiotowej adresatami norm prawnych są ludzie niezależnie od cech ich określających. W sposób szczególny na ww. zjawiska narażone są osoby w młodym wieku. W związku z tym warto dokonać analizy sfery prawnej na etapie tworzenia, stosowania i egzekwowania prawa, która odnosi się do ochrony bezpieczeństwa dzieci w kontekście zmian technologicznych, a ściślej mówiąc, w cyberprzestrzeni, gdzie klasyczne paradygmaty często bywają nieadekwatne. Wybór tematu niniejszych rozważań, uzasadnia również fakt skromnych opracowań na ten temat, które autorzy dostrzegli w literaturze przedmiotu, a co za tym idzie niniejszy tekst może przysłużyć się rozwojowi badań w tej materii. Celem niniejszych rozważań jest badanie tego, czy prawo rozproszone w rozmaitych aktach prawnych skutecznie zabezpiecza interesy dzieci w korzystaniu z dobrodziejstw nowych technologii, których areną, w głównej mierze jest cyberprzestrzeń. Oprócz tego warto zastanowić się czy zespół norm prawnych dotyczących bezpieczeństwa dzieci w cyberprzestrzeni można nazwać systemem, czy jest to raczej zbiór, zespół powiązanych tematycznie praw. Warto podkreślić, że zakładanym efektem będzie także systematyzacja prawa dotyczącego poruszanego zagadnienia. Przestrzeń badawczą stanowić będzie działalność Organizacji Narodów Zjednoczonych, Rada Europy.

\section{Definicje}

Rozważania na powyższy temat należy rozpocząć od próby zdefiniowania jego składowych, czyli pojęć: bezpieczeństwo, dzieci, cyberprzestrzeń. $W$ literaturze przedmiotu pojęcia te często nie są jednoznacznie określane, a ich używanie zależy od kontekstu, w którym są rozpatrywane. Przedmiotowe zagadnienia będą rozpatrywane w uję-

\footnotetext{
2 M. Castells, Społeczeństwo sieci, Warszawa 2007, s. 23-24.
} 
Mateusz K. Maciejczuk et al. - Cyberprzestępczość a bezpieczeństwo...

ciu teoretycznym, a także w uzasadnionych przypadkach podjęta będzie próba wskazania elementów praktycznych.

\subsection{Bezpieczeństwo}

W doktrynie można odnaleźć wiele definicji tego pojęcia. Źródeł pojęcia „bezpieczeństwo” doszukuje się w łacińskim słowie securitas, które pochodzi od sine cura, oznaczającego dosłownie stan „bez pieczy"3. W Słowniku języka polskiego bezpieczeństwo zostało określone jako stan niezagrożenia, spokoju, pewności4. Etymologia tego słowa w wielu językach odnosi się do omawianego pojęcia jako do pewnego stanu, który wskazuje pierwotność poczucia zagrożenia w stosunku do poczucia pewności swego zabezpieczeni ${ }^{5}$. Według akceptowalnego i powszechnie przyjętego rozumienia bezpieczeństwa można stwierdzić, iż zagrożenie stanowi przeciwieństwo bezpieczeństwa i oznacza możliwość wystąpienia pejoratywnie ocenianego zjawiska lub sytuacji, działania, które godzą w dane wartości lub są względem ich niebezpieczne ${ }^{6}$ Słowo „bezpieczeństwo”, jak zauważa L. F. Korzeniowski odzwierciedla dualny stan: obiektywny rozumiany jako „stan zagrożenia”;;,przeciwieństwo zagrożenia"9; ,,być bezpiecznym”10, albo subiektywny określany jako „stan psychiczny lub prawny, w którym jednostka ma poczucie pewności, oparcie w drugiej osobie lub w sprawnie działającym systemie prawnym”11; „stan (...) spokoju, pewności”12;

${ }^{3}$ R. Zięba, Kategoria bezpieczeństwa $w$ nauce o stosunkach międzynarodowych, [w:] Bezpieczeństwo narodowe i międzynarodowe u schyłku XX wieku, D. B. Bobrov, E. Haliżak, R. Zięba, (red.), Warszawa 1997, s. 3.

4 Słownik języka polskiego, M. Szymczak (red.), Warszawa 1978, s. 147.

5 Bezpieczeństwo $w$ teorii i badaniach naukowych, B. Wiśniewski (red.), Szczytno 2011, s. 12.

${ }^{6}$ M. Brzeziński, Kategoria bezpieczeństwa, [w:] Bezpieczeństwo wewnętrzne państwa. Wybrane zagadnienia, S. Sulkowski (red.), M. Brzeziński (red.), Warszawa 2009, s. 23.

7 L. F. Korzeniowski, Podstawy nauk o bezpieczeństwie, Warszawa 2012, s. 75-76.

8 Słownikjęzyka..., op. cit., s. 147.

9 Słownik współczesnego języka polskiego, B. Dunaj (red.), Warszawa 2001, t. 1, S. 50 .

10 S. Skorupska, Słownik frazeologiczny języka polskiego, Warszawa 1987, s. 98.

11 Słownik współczesnego..., op. cit. 
„poczuć się bezpiecznym”13. W związku z tym stan bezpieczeństwa może być osiągnięty wówczas, gdy jednocześnie zmaterializują się przesłanka obiektywna (brak rzeczywistego zagrożenia) oraz subiektywna (brak poczucia zagrożeń) ${ }^{14}$. Istotne jest także ujmowanie samego zagrożenia, które może być rozumiane jako sytuacja, w której powstaje prawdopodobieństwo powstania stanu niebezpiecznego dla otoczenia ${ }^{15}$. Istnieją także definicje zagrożenia, które odwołują się do jego cech, czyli natężenia oraz miejsca występowania ${ }^{16}$, które jest szczególnie istotne, gdyż nie chodzi tylko o kryterium geograficzne, gdyż może być to cyberprzestrzeń, warstwa społeczna, warstwa ochrony środowiska, warstwa gospodarki globalnej itp. ${ }^{17}$.

W związku z wieloma definicjami proponowanymi przez przedstawicieli piśmiennictwa należy przyznać rację J. Stańczykowi, który stwierdził, iż nie istnieje jedna, wspólnie uzgodniona definicja bezpieczeństwa, która zostałaby przyjęta w sposób uniwersalny ${ }^{18}$ czego dowodzi istnienie innych konstrukcji owego terminu ${ }^{19}$. Może być to spowodowane czynnikami geograficznymi, temporalnymi czy też prawnymi, społecznymi, politycznymi lub ekonomicznymi ${ }^{20}$. J. Czaputowicz twierdzi, iż badacze są raczej zgodni w kwestii, iż bezpieczeń-

12 Słownik języka..., op. cit., s. 147.

${ }^{13}$ S. Skorupska, Słownik frazeologiczny..., op. cit., s. 98.

${ }^{14}$ Bezpieczeństwo w teorii i badaniach..., s. 14.

15 D. Majchrzak, Europejska polityka bezpieczeństwa i obrony, [w:] Bezpieczeństwo $w$ dobie globalizacji. Prawo i praktyka, M. Kun-Buczko, M. Przybysz (red.), Białystok 2011, s. 165.

16 Słownik z zakresu bezpieczeństwa MON, Warszawa 1996, s. 117.

17 D. Majchrzak, Europejska polityka ..., op. cit. s. 165.

18 J. Stańczyk. Współczesne pojmowanie bezpieczeństwa, Warszawa 1996, s. 17.

19 Przykład definicji na podkreślenie wielości ujęć: „Bezpieczeństwo to pewien stan, który daje poczucie pewności, i gwarancje jego zachowania oraz szansę na doskonalenie. Jedna z podstawowych potrzeb człowieka. To sytuacja odznaczająca się brakiem ryzyka utraty czegoś co człowiek szczególnie ceni, na przykład zdrowia, pracy, szacunku, uczuć, dóbr materialnych", [w:] Słownik terminów z zakresu psychologii dowodzenia i zarzq̨dzania, Warszawa 2000, s. 17.

20 Zob. P. Majer, $W$ poszukiwaniu uniwersalnej definicji bezpieczeństwa wewnętrznego, „Przegląd Bezpieczeństwa Wewnętrznego” 2012, nr 7. 
Mateusz K. Maciejczuk et al. - Cyberprzestępczość a bezpieczeństwo...

stwo jest wartością stopniowalną, czyli dany podmiot może być mniej lub bardziej bezpieczny lub posiadać takie poczucie ${ }^{21}$.

\subsection{Cyberprzestrzeń}

Pierwsze użycie i dalsze rozpowszechnianie pojęcia cyberprzestrzeń przypisuje się Williamowi Gibsonowi, który posłużył się nim w opowiadaniu, które opublikowano w magazynie „Omni” w 1982 r. 22, a potem w powieści Neuromancer wydanej w 1984 r. $^{23}$, gdzie pisał o świecie: „(...) cyberprzestrzeń. Konsensualna halucynacja, doświadczana każdego dnia przez miliardy uprawnionych użytkowników we wszystkich krajach, przez dzieci nauczone pojęć matematycznych (...). Graficzne odwzorowanie danych pobieranych z banków wszystkich komputerów świata. Niewyobrażalna złożoność. Liczne światła przebiegające przez mroczną przestrzeń umysłu, skupiska i konstelacje danych do złudzenia przypominające światła wielkiego miasta"24. W sposób oczywisty owa definicja nie jest wystarczająca wobec wymogów rozważań naukowych. Cyberprzestrzeń w literaturze przedmiotu określa się jako ogół powiązań o charakterze wirtualnym („nieprzestrzennym" w sensie fizycznym, niematerialnym i geograficznym), które powstały i funkcjonują dzięki ich fizycznym gwarantom (komputery, infrastruktura telekomunikacyjna) ${ }^{25}$. Reasumując można stwierdzić, iż cyberprzestrzeń to „całość powiązań ludzkiej działalności z udziałem ICT (Information and Communication Technology) ${ }^{26}$. Warto wskazać na wybrane immanentne cechy cyberprzestrzeni,

\footnotetext{
21 J. Czaputowicz, Bezpieczeństwo międzynarodowe. Wspótczesne koncepcje, Warszawa 2012, s. 23.

${ }^{22}$ http://www.britannica.com/EBchecked/topic/410654/Neuromancer, [dostęp: 15-06-2017].

23 W. Gibbson, Neuromancer, New York 1989, s. 128.

${ }^{24}$ Przekład na język polski za: J. Kosiński, Paradygmaty cyberprzestępczości, Warszawa 2015, s. 32.

25 M. Madej, Rewolucja informatyczna - istota, przejawy oraz wpływ na postrzeganie bezpieczeństwa państw i systemu międzynarodowego, [w:] M. Madej, M. Terlikowski (red.), Bezpieczeństwo teleinformatyczne państwa, Warszawa 2009, s. 28.

${ }^{26}$ A. Bogdół-Brzezińska, M. F. Gawrycki, Cyberterroryzm i problemy bezpieczeństwa informacyjnego we współczesnym świecie, Warszawa 2003, s. 37.
} 
które dostrzega doktryna: uniezależnienie się od przestrzeni geograficznej, obniżający się koszt wejścia i korzystania z sieci, anonimowość i zacieranie śladów oraz posiada cechę otwartości na nowych użytkowników ${ }^{27}$. Rozważania naukowe $\mathrm{z}$ zakresu prawa wymagają definicji legalnych określonych zjawisk czy pojęć. Warto podkreślić, że nie ma jedynej, międzynarodowej definicji legalnej cyberprzestrzeni. Eksperci podkreślają wielowymiarowość cyberprzestrzeni, którą należy rozpatrywać w aspekcie ludzkim i technicznym. Do cech cyberprzestrzeni zalicza się: plastyczność, płynność, obliczalność, dokładność, powtarzalność, hipertekstowość, interaktywność, wizualność, kompatybilność, otwartość, nieograniczoność, wszechstronność, złożoność, sieciowość, przenikliwość, konwergentność, konsolidację, automatyzację i totalność ${ }^{28}$. W literaturze przedmiotu autorzy komentując powyższe ujęcie cyberprzestrzeni wskazują na jego mankamenty ${ }^{29}$, ale na potrzeby niniejszych rozważań wystarczające będą definicje przedstawiane w literaturze przedmiotu ${ }^{30}$.

\subsection{Dzieci}

W literaturze przedmiotu istnieje wiele definicji dziecka, ale za najbardziej uniwersalną należy uznać tę z art. 1 Konwencji o prawach dziecka z 1989 r., która stanowi, iż dzieckiem jest istota ludzka przed ukończeniem 18 roku życia, chyba że zgodnie z prawem odnoszącym

27 T. R. Aleksandrowicz, K. Liedel, Społeczeństwo informacyjne - sieć - cyberprzestrzeń. Nowe zagrożenia, [w:] K. Liedel, P. Piasecka, T. R. Aleksandrowicz (red.), Sieciocentryczne bezpieczeństwo, Warszawa 2014, s. 24.

${ }^{28}$ J. Janowski, Cybernetyzacja prawa, [w:] E. Galewska, S. Kotecka (red.), X-lecie CBKE. Ksiegga pamiątkowa z okazji 10-lecia Centrum Badań Problemów Prawnych i Ekonomicznych Komunikacji Elektronicznej i Studenckiego Koła Naukowego, Warszawa 2012, s. 394.

${ }^{29}$ Zob. szerz. K. Liderman, Analiza wybranych pojęć dokumentu Polityka Ochrony Cyberprzestrzeni Rzeczypospolitej Polskiej, http://www.ita.wat.edu.pl/data/ita/7cf74 de3e6ce1531322d80719c7968c2.html?ts=1390808700, [dostęp 17-06-2017].

30 Zob. The National Strategy for Cyberspace, February 2003, http://www.hsdl. org/?view\&did=1040, [dostęp: 15-06-2017]. 
Mateusz K. Maciejczuk et al. - Cyberprzestępczość a bezpieczeństwo...

się do dziecka uzyska ono wcześniej pełnoletniość31. Konwencję ratyfikowały 193 państwa, co jest najwyższym wynikiem wśród aktów, którymi związali się członkowie społeczności międzynarodowej. Warto podkreślić, iż inne definicje traktatowe, są zbieżne $\mathrm{z}$ pewnymi wyjątkami, co obrazuje poniższa tabela.

Tabela 1. Definicje dziecka w wybranych aktach prawnych

\begin{tabular}{|c|c|}
\hline Definicja & Źródło \\
\hline $\begin{array}{l}\text { „niniejsza konwencja ma zastosowanie } \\
\text { do osób, które nie ukończyły } 18 \text { roku } \\
\text { życia” }\end{array}$ & $\begin{array}{l}\text { Art. } 1 \text { ust. } 1 \text { Europejskiej konwencji o wy- } \\
\text { konywaniu praw dzieci } 32\end{array}$ \\
\hline $\begin{array}{l}\text { „wyrażenie dziecko oznacza osobę, } \\
\text { niezależnie od jej obywatelstwa, która } \\
\text { nie ukończyła 16. roku życia i która, } \\
\text { zgodnie z prawem państwa jej stałego } \\
\text { zamieszkania, jej prawem ojczystym } \\
\text { lub państwa wezwanego, nie może sa- } \\
\text { modzielnie decydować o swym miej- } \\
\text { scu zamieszkania” }\end{array}$ & $\begin{array}{l}\text { Art. } 1 \text { lit. a) Europejskiej Konwencji } \\
\text { o uznawaniu i wykonywaniu orzeczeń } \\
\text { dotyczących pieczy nad dzieckiem oraz } \\
\text { o przywracaniu pieczy nad dzieckiem }{ }^{33}\end{array}$ \\
\hline $\begin{array}{l}\text { „dziecko oznacza każdą osobę, która } \\
\text { nie ukończyła } 18 \text { lat lub wieku, do któ- } \\
\text { rego orzeczenie dotyczące kontaktu } \\
\text { może być wydane lub wykonywane } \\
\text { w umawiającym się państwie” }\end{array}$ & $\begin{array}{l}\text { Art. } 2 \text { lit. c) Konwencji } \mathrm{w} \text { sprawie } \\
\text { kontaktów z dziećmi }{ }^{34}\end{array}$ \\
\hline $\begin{array}{l}\text { „dziecko oznacza każdą osobę poniżej } \\
18 \text { roku życia” }\end{array}$ & $\begin{array}{l}\text { Art. } 3 \text { pkt. 1) Konwencji Rady Europy } \\
\text { o ochronie dzieci przed seksualnym wy- } \\
\text { korzystywaniem i niegodziwym traktowa- } \\
\text { niem w celach seksualnych } 35\end{array}$ \\
\hline
\end{tabular}
526).

${ }^{31}$ Konwencja o ochronie praw dziecka z 20.11 .1989 r. (Dz. U. 1991, nr 120, poz.

${ }^{32}$ Europejska konwencja o wykonywaniu praw dzieci, z 25.01.1996 r. (Dz. U. 2000, $\mathrm{nr} 107$, poz. 1128).

${ }^{33}$ Europejska Konwencja o uznawaniu i wykonywaniu orzeczeń dotyczq̨cych pieczy nad dzieckiem oraz o przywracaniu pieczy nad dzieckiem z 20.05.1980 r. (Dz. U. 1996, nr 31, poz. 134).

${ }^{34}$ Konwencja w sprawie kontaktów z dziećmi z 15.05.2003 r., ETS nr 192.

35 Konwencja Rady Europy o ochronie dzieci przed seksualnym wykorzystywaniem i niegodziwym traktowaniem w celach seksualnych z 12.07.2007 r., https://ms.gov.pl/ Data/Files/_public/ppwd/akty_prawne/rada_europy/-konwe2.pdf, [dostęp: 19-062017]. 
W aktach prawa międzynarodowego oprócz terminu „dziecko” używane są także inne określenia, tj.:

- „młodociany” - art. 10 ust. 2 lit. b) oraz art. 14 ust. 1 i 4 Międzynarodowego Paktu Prawa Obywatelskich i Politycznych z 1966 r. ${ }^{36}$;

- „małoletni” - art. 24 ust. 1 Międzynarodowego Paktu Prawa Obywatelskich i Politycznych z 1966 r. ${ }^{37}$; art. 9 Konwencji Rady Europy o cyberprzestępczości z dnia 23 listopada 2001 r.38;

- „nieletni” - art. 76 IV Konwencji Genewskiej o ochronie osób cywilnych podczas wojny z $1949 \mathrm{r}^{39}$;

- „dzieci i młodzież” - art. 94 IV Konwencji Genewskiej o ochronie osób cywilnych podczas wojny z $1949 \mathrm{r}^{40}$ oraz art. 10 ust. 3 Międzynarodowego Paktu Praw Społecznych, Gospodarczych i Kulturalnych z $1966 \mathrm{r}^{41}$.

W związku z powyższym należy przyznać rację P. Jarosowi, który twierdzi, iż termin „dziecko” na gruncie prawa międzynarodowego nie jest jednoznaczny, gdyż spotykany jest w różnym kontekście i w odniesieniu do różnych uprawnień formułowanych w poszczególnych aktach, czego wynikiem jest fakt, iż to pojęcie nie znalazło definicji, która mogłaby uzyskać powszechne uznanie ${ }^{42}$. Problematyczne kwestia to oparcie definicji Konwencji o Prawach Dziecka o kryterium wieku, gdzie nie doprecyzowano statusu dzieci poczętych a nienarodzonych. W związku z problematyką bezpieczeństwa w cyberprze-

${ }^{36}$ Międzynarodowy Pakt Praw Obywatelskich i Politycznych z 19.12.1966 r. (Dz. U. 1977, $\mathrm{nr}$ 38, poz. 137).

37 Ibidem.

${ }^{38}$ Konwencja Rady Europy o cyberprzestepczości z dnia 23 listopada 2001 r. (Dz. U. 2015, poz. 728).

${ }^{9}$ IV Konwencja Genewska o ochronie osób cywilnych podczas wojny z 12.08.1949 r. (Dz. U. 1956, nr 38, poz. 171 z późn. zm.). Warto podkreślić, że w art. 132 IV Konwencja Genewska zawiera takie pojęcia jak: „dzieci”, „niemowlęta” i „małe dzieci”.

40 Ibidem.

41 Międzynarodowy Pakt Praw Społecznych, Gospodarczych i Kulturalnych z 19.12. 1966 r. (Dz. U. 1977, nr 38, poz. 169).

42 P. Jaros. Definicja dziecka, [w:] S. L. Stadniczeńko (red.), Konwencja o prawach dziecka. Wybór zagadnień (artykuły i komentarze), Warszawa 2015, s. 51. 
Mateusz K. Maciejczuk et al. - Cyberprzestępczość a bezpieczeństwo...

strzeni ww. kwestia nie jest kluczowym elementem prowadzonej analizy choć w doktrynie wzbudza wiele kontrowersji ${ }^{43}$.

\section{Bezpieczeństwo dzieci w cyberprzestrzeni a prawo}

W Polityce Ochrony Cyberprzestrzeni Rzeczypospolitej Polskiej przyjętej w 2013 r. zawarta jest definicja bezpieczeństwa cyberprzestrzeni jako „(...) zespół przedsięwzięć organizacyjno-prawnych, technicznych, fizycznych i edukacyjnych mający na celu zapewnienie niezakłóconego funkcjonowania cyberprzestrzeni”, która może stanowić syntetyczne połączenie pojęć bezpieczeństwa i cyberprzestrzeni ${ }^{44}$. W związku z powyższym należy odpowiedzieć sobie na pytanie o zjawiska, które zagrażają dzieciom w ww. przestrzeni. Pojęciem, które w najszerszy sposób odpowiada na tę kwestię jest: cyberprzestępczość. Pojęcie to w sposób klarowny wyjaśnia Komunikat Komisji Europejskiej Strategia bezpieczeństwa cybernetycznego Unii Europejskiej: otwarta, bezpieczna i chroniona cyberprzestrzeń z 2013 r., która stanowi, iż: „cyberprzestępczość ogólnie odnosi się do szerokiego wachlarza różnych rodzajów działalności przestępczej, w przypadku której komputery i systemy informatyczne stanowią podstawowe narzędzie przestępcze lub są głównym celem działania przestępczego. Cyberprzestępczość obejmuje tradycyjne przestępstwa związane (np. nadużycia finansowe, fałszerstwa i kradzież tożsamości), przestępstwa związane z treściami (np. dystrybucja w Internecie pornografii dziecięcej lub nawoływanie do nienawiści rasowej) oraz przestępstwa typowe dla komputerów i systemów informatycznych (np. ataki na systemy informatyczne, w tym ataki prowadzące do zablokowania usług/systemów, oraz złośliwe oprogramowanie)”45. Warto

43 Zob. G. Michałowska, Międzynarodowa ochrona praw dziecka, Warszawa 2016, s. 30-34, P. Jaros. Definicja dziecka..., op. cit., s. 51-62.

44 http://www.cert.gov.pl/cer/publikacje/polityka-ochrony-cyber/639,PolitykaOchrony-Cyberprzestrzeni-Rzeczypospolitej-Polskiej.html [dostęp: 15-06-2017].

45 http://www.europarl.europa.eu/meetdocs/2009_2014/documents/join/com_ join(2013)0001_/com_join(2013)0001_pl.pdf [dostęp: 19-06-2017]. 
podkreślić, że katalog przestępstw w cyberprzestrzeni stale pozostaje otwarty. Jest to tym bardziej poważne zagrożenie dla dzieci, które coraz częściej posiadają stały dostęp do urządzeń za pomocą, których stają się użytkownikami cyberprzestrzeni - często nieświadomie, dlatego w literaturze przedmiotu niektórzy autorzy określają je jako dzieci sieci, czyli tzw. sieciaki ${ }^{46}$, pokolenie „kopiuj-wklej”, pokolenie „kciuka” czy też - jak określa to raport Dzieci aktywne online - „urodzeni z myszką w ręku” 47 , albo „cyfrowi tubylcy” jak opisał ich M. Prensky48.

Początki tworzenia współcześnie rozumianej prawnej ochrony praw dziecka sięgają drugiej połowy XIX wieku ${ }^{49}$. Oczywiście były to działania nieskoordynowane, do których bodźcem stała się aktywność społeczników, rozwój przemysłu, debaty na arenie międzynarodowej ${ }^{50}$. Najważniejszym skutkiem ww. działań było przyjęcie w $1924 \mathrm{r}$. Deklaracji Praw Dziecka (znana jako Deklaracja Genewska) przez Ligę Narodów $51 . W$ kontekście rozwoju ochrony praw dziecka warto podkreślić, iż jej realizacja w oderwaniu od ochrony praw człowieka, praw rodziny nie spełni swojego celu i może przynieść więcej strat niż korzyści, gdyż prawa dziecka są ściśle powiązane z ochroną autonomii i praw rodziny oraz charakteryzują się związkiem ze społecznym wymiarem egzystencji ${ }^{52}$. W związku z tym zauważa się, że prawa dziecka są immanentnym elementem systemu ochrony praw człowieka na świecie.

\footnotetext{
46 E. Bendyk, Sieciaki, http://www.polityka.pl/tygodnikpolityka/nauka/278207, 1,sieciaki.read, [dostęp: 19-06-2017].

${ }^{47}$ Dzieci aktywne online, 2007; M. Szpunar, Urodzeni z myszkq w ręku, [w:] J. Morbitzer (red.), Komputer w edukacji, Kraków 2009, s. 261-267.

48 M. Prensky, Digital Natives, Digital Immigrants, http://www.marcprensky.com/ writing/Prensky\%20-\%20Digital\%20Natives,\%20Digital\%20Immigrants\%20-\%20P art1.pdf, [dostęp: 19-06-2017].

49 J. Szymańczak, Prawny zakaz fizycznego karania dzieci, „Infos” 2009, nr 6 (53).

50 G. Michałowska, Międzynarodowa ochrona..., op. cit., s. 20-25.

51 Z. Rudnicki, Deklaracja Genewska praw dziecka z 1924 roku, [w:] E. Karska (red.),Prawa dziecka w prawie międzynarodowym, Warszawa 2013.

${ }^{52}$ S. L. Stadniczeńko, Prawa człowieka częściq składowa systemu praw człowieka i obywatela, [w:] S. L. Stadniczeńko (red.), Konwencja o prawach dziecka. Wybór zagadnień (artykuły i komentarze), Warszawa 2015, s. 47.
} 
Mateusz K. Maciejczuk et al. - Cyberprzestępczość a bezpieczeństwo...

\subsection{Organizacja Narodów Zjednoczonych}

Po II wojnie światowej aktem o zasadniczym znaczeniu w kwestii nadania statusu międzynarodowego problematyce ochrony praw dziecka niewątpliwie jest Powszechna Deklaracja Praw Człowieka, przyjęta przez Zgromadzenie Ogólne ONZ w 1948 r., która stanowi, iż: „wszyscy ludzie rodzą się wolni i równi w swej godności i w swych prawach” (art. 1), a następnie: „zapewnia prawo do korzystania ze swych praw i wolności zawartych w dokumencie bez względu na różnice rasy, koloru skóry, płci (...) narodowości pochodzenia społecznego, majątku, urodzenia” (art. 2); w art. 25 czytamy, że „macierzyństwo i dzieciństwo upoważniają do specjalnej opieki i pomocy, i deklaruje, że wszystkie dzieci, zarówno małżeńskie, jak pozamałżeńskie będą korzystać z jednakowej pomocy społecznej”53. Analiza treści Deklaracji wskazuje na to, iż dzieci nie są w centrum jej zainteresowania, gdyż słowo „dzieci”, „dziecko” pojawia się w tekście dwukrotnie, a słowo „dzieciństwo” tylko raz. Jednak warto przytoczyć i poprzeć stanowisko Uché Ewelukwa, który twierdzi, iż to właśnie art. 16, 25 i 26 Deklaracji stanowią fundamenty rozwoju ochrony praw dziecka, a już sposób szczególny na kontynencie afrykańskim pomimo tego, iż w kolejnych latach nie przyjęto żadnych szczegółowych regulacji w owej materii, to Deklaracja stanowiła impuls w świadomości społeczności międzynarodowej do konieczności ochrony dzieci54. Jak słusznie zauważa G. Michałowska trudno się dziwić, gdyż w tamtym okresie dorośli sami nie posiadali wyznaczonych praw powszechnymi umowami międzynarodowymi, dlatego temat ochrony dzieci był drugoplanowy55. Dopiero w 1959 r. Zgromadzenie Ogólne ONZ przyjęło Deklarację Praw Dziecka, która odwoływała się do Deklaracji Genewskiej (1924) i Powszechnej Deklaracji Praw Człowieka (1948), której za-

53 Powszechna Deklaracja Praw Człowieka z 10.12.1948 r., http://libr.sejm.gov. pl/tek01/txt/onz/1948.html, [dostęp: 19-06-2017].

54 U. E. Ofodile, The Universal Declaration of Human Rights and the African Child Today: Progress Or Problems?, „American University International Law Review” 2010, nr 2(5), s. 37-41.

55 G. Michałowska, Międzynarodowa ochrona..., op. cit., s. 26. 
sadniczym celem było zapewnienie dziecku szczęśliwego dzieciństwa i korzystania zarówno w jego interesie, jak i w interesie społeczeństwa z zawartych w niej praw i swobód 56 . Warto podkreślić, że obydwie Deklaracje posiadały charakter intencjonalny i ich rola ograniczyła się do wytyczania standardów, czego dowodzi ich tzw. miękki charakter. Należy także wspomnieć o postanowieniach Międzynarodowego Paktu Praw Obywatelskich i Politycznych z 19 grudnia 1966 r., który stanowi, iż nie wolno wydawać wyroku śmierci za przestępstwo popełnione przez osobę, która nie ukończyła 18 roku życia, a każde dziecko bez jakiejkolwiek dyskryminacji ze względu na rasę, kolor, płeć, język, religię, pochodzenie narodowe lub społeczne. Sytuację majątkową lub urodzenie, ma prawo do ochrony, jakiej wymaga status małoletniego, ze strony rodziny, społeczeństwa i państwa ${ }^{57}$. Wykładnia przepisu stanowiącego o wyłączeniu dziecka spod kary śmierci za popełnione przestępstwa dotyczy także tych, które popełnione są w cyberprzestrzeni. Oprócz tego Międzynarodowy Pakt Praw Ekonomicznych, Społecznych i Kulturalnych z 19 grudnia 1966 r. także podkreśla fakt, iż należy podejmować specjalne środki w celu zapewnienia ochrony wszystkim dzieciom i młodzieży bez jakiejkolwiek dyskryminacji ${ }^{58}$. W tym kontekście warto pokusić się o komentarz co do możliwości odniesienia gwarancji z ww. dokumentów wobec bezpieczeństwa dzieci w cyberprzestrzeni. W sposób oczywisty intencją autorów powyższych było uniwersalne zabezpieczenie pozycji prawnej dzieci. Cyberprzestrzeń w latach 60. XX wieku dla prawodawców była jeszcze czymś odległym, a mimo to konstrukcja przepisów umożliwia odnoszenie ich do cyberprzestrzeni $w$ takich aspektach jak karanie dzieci za czyny popełnione w wirtualnym świecie czy też za-

${ }^{56}$ Deklaracja Praw Dziecka z 20.11.1959 r., http://libr.sejm.gov.pl/tek01/txt/onz/ 1959.html, [dostęp: 19-06-2017].

57 Międzynarodowy Pakt Praw Obywatelskich i Politycznych z 19.12.1966 r. (Dz. U. 1977, nr 38, poz. 167).

58 Międzynarodowy Pakt Praw Społecznych, Gospodarczych i Kulturalnych z 19.12. 1966 r. (Dz. U. 1977, nr 38, poz. 169). 
Mateusz K. Maciejczuk et al. - Cyberprzestępczość a bezpieczeństwo...

kaz dyskryminacji, który można odnieść do gwarantowania dostępu przez państwa do nowych technologii.

W końcu 20 listopada 1989 r. Zgromadzenie Ogólne NZ jednomyślnie uchwaliło Konwencję o Prawach Dziecka ${ }^{59}$, która w literaturze przedmiotu określana jest jako „konstytucja praw dziecka”60. Warto podkreślić, iż Konwencja powstała z inicjatywy Polski, która w 1978 r. zaproponowała jej projekt, a główne role w jej tworzeniu odegrali: prof. A. Łopatka oraz prof. T. Smyczyński ${ }^{61}$. Postanowienia niniejszej Konwencji nie odnoszą się wprost do kwestii cyberprzestrzeni najprawdopodobniej z racji okresu jej przyjęcia. Jednak nie powinno to zniechęcać do pochylenia się nad jej treścią. Warto podkreślić, iż Konwencja w art. 3 ust. 1 stanowi, iż „we wszystkich działaniach dotyczących dzieci, podejmowanych przez publiczne lub prywatne instytucje opieki społecznej, sądy, władze administracyjne lub ciała ustawodawcze, sprawą nadrzędną będzie najlepsze zabezpieczenie interesów dziecka", a w ust. 3 Konwencja nakłada na Państwa Strony obowiązek czuwania nad instytucjami, służbami oraz innymi jednostkami odpowiedzialnymi za opiekę lub ochronę dzieci, aby te dostosowały się do norm ustanowionych przez kompetentne władze, w szczególności w dziedzinach bezpieczeństwa, zdrowia, jak również dotyczących właściwego doboru kadr tych instytucji oraz odpowiedniego nadzoru62. Na podstawie art. $13 \mathrm{w}$ kontekście art. 17 Konwencji wynika prawo dziecka do ochrony przed informacjami szkodliwymi dla jego rozwoju ${ }^{63}$. W sposób szczególny warto podkreślić kwestię bezpieczeństwa, która jest aktualna w kontekście działania dzieci w cyberprzestrzeni. Konwencja w swej treści odnosi się głównie do przestrzeni geograficznej, czyli państw, ale jest jej zapisy posiadają

${ }^{59}$ Konwencja o Prawach Dziecka z 20.11.1989 r. (Dz. U. 1991, nr 120, poz. 526).

${ }^{60}$ A. Łopatka, Dziecko. Jego prawa człowieka, Warszawa 2000, s. 19.

${ }^{61}$ P. J. Jaros, M. Michalak, Prawa dziecka. Dokumenty Organizacji Narodów Zjednoczonych, Warszawa 2015, s. 197.

62 Konwencja o Prawach Dziecka z 20.11.1989 r. (Dz. U. 1991, nr 120, poz. 526).

${ }^{63}$ M. Braun-Gałkowska, Prawo dziecka do poszukiwania i przekazywania informacji (wpływ środków masowego przekazu na dziecko), [w:] T. Smyczyński (red.), Konwencja o prawach dziecka - analiza I wykładnia, Poznań 1999, s. 233. 
charakter generalny i abstrakcyjny, co pozwala na ich odniesienie w kontekście cyberprzestrzeni czy cyberbezpieczeństwa, co nie jest zbyt odważnym wnioskiem pomimo uwarunkowań technologicznych w momencie jej przyjmowania. ONZ w swych działaniach dostrzegł także zjawisko rosnącego wpływu cyberprzestrzeni na życie dzieci. Ocena Konwencji jest wielowymiarowa, gdyż jak zauważa J. Hall jej najmocniejszą stroną jest to, że w ogóle istnieje, a za słabe punkty przypisuje jej zbyt miękki charakter, który przypomina deklarację niż akt posiadający cechy hard law i jako taka nie ma charakteru wiążącego ${ }^{64}$. Oczywiście jest to jeden z głosów bardziej krytycznych, które są przedstawiane $\mathrm{w}$ doktrynie, a przeważająca część autorów ocenia skutki Konwencji pozytywnie pomimo zgłaszanych wątpliwości. Istotna wydaje się treść Protokołu Fakultatywnego do Konwencji o Prawach Dziecka w sprawie handlu dziećmi, dziecięcej prostytucji i dziecięcej pornografii, w którym Państwa-Strony wyrażają zaniepokojenie rosnąca dostępnością dziecięcej pornografii w Internecie i innych rozwijających się technologiach w odniesieniu do „Międzynarodowej konferencji w sprawie zwalczania dziecięcej pornografii w Internecie" (Wiedeń 1999), a w sposób szczególny do wniosku, który mówi o wadze bliższej współpracy między rządami a przemysłem internetowym ograniczania tego zjawiska65. W Aneksie Wskazania Narodów Zjednoczonych dotyczących zapobiegania przestępczości nieletnich, czyli tzw. Wskazaniach Rijadskich poruszono kwestie środków masowego przekazu, które de facto, obecnie funkcjonują w cyberprzestrzeni i wytyczono zadania podmiotom dysponującym tego typu środkami, aby ograniczyli do minimum ukazywanie pornografii, narkotyków i przemocy w trosce o dobro dzieci66. Natomiast w Komentarzu Ogólnym Komitetu Praw Dziecka nr 17 z 2013 r. dostrzeżono coraz większą rolę mediów elektronicznych, które stają się głównym wymiarem codziennej rzeczywistości dzieci, które z łatwością poruszają się po-

\footnotetext{
64 J. Hall (red.), Children's Human Rights and Public Schooling in the United States, Sense Publishers, Rotterdam-Boston-Taipei 2013 r., s. 9.

65 P. J. Jaros, M. Michalak, Prawa dziecka..., op. cit., s. 241-243.

66 Ibidem, s. 332.
} 
Mateusz K. Maciejczuk et al. - Cyberprzestępczość a bezpieczeństwo...

między realnym i wirtualnym światem ${ }^{67}$. Komitet zauważa, iż: „dostęp do Internetu i mediów społecznościowych naraża dzieci na przemoc w cyberprzestrzeni, pornografię i nagabywanie w sieci w celach seksualnych..."68. Ponadto na forum ONZ stale poruszana jest problematyka cyberbezpieczeństwa w kontekście ludzi, a w tym dzieci. Większość działań ma charakter analityczny i polega na przekazywaniu rekomendacji państwom co do działań niwelujących zagrożenie cyberprzestępczości. Dorobek ONZ w zakresie bezpieczeństwa dzieci w cyberprzestrzeni można oceniać wieloaspektowo. Jeśli ocena skupiłaby się na ilości aktów prawnych o charakterze wiążącym to z pewnością spowodowałoby to niedosyt. Jednak istotna jest treść i zakres działań oraz podejmowanie szeregu inicjatyw, które w określonych przypadkach mogą przynieść więcej korzyści niż skomplikowane zapisy prawne ${ }^{69}$.

\subsection{Rada Europy}

W dorobku Rady Europy ochrona dzieci i młodzieży posiada rozbudowane regulacje prawne, co świadczy o doniosłości materii oraz aktywności jej członków. W pierwszej kolejności należy wyróżnić Europejską Kartę Społeczną z 1961 r., które art. 7 zawiera zobowiązanie Państw do zapewniania dziecku szczególnej ochrony przed fizycznymi i moralnymi zagrożeniami, a z kolei art. 24 Karty stanowi, iż dzieci mają prawo do ochrony i opieki, jaka jest konieczna dla ich dobra, a wszystkie działania dotyczące małoletnich, zarówno podejmowane przez władze publiczne jak i instytucje prywatne, należy podporządkować najlepszym interesom dziecka ${ }^{70}$. Na forum Rady Europy do problematyki zabezpieczenia interesów dzieci odnosiły się: w art. 2, 3 oraz 10 Europejskiej Konwencji o Ochronie Praw Człowieka

\footnotetext{
67 Ibidem, s. 781.

68 Ibidem.

${ }^{69}$ Zob. na temat inicjatyw podejmowanych przez ONZ w kontekście cyberprzestępczości: http://www.unic.un.org.pl/przestepczosc2015/39,2698, [dostęp: 19-062017].

${ }^{70}$ Europejska Karta Społeczna z 18.12.1961 r. (Dz. U. 1999, nr 8, poz. 67 z późn.
} $\mathrm{zm}$.). 
i Podstawowych Wolności z 1950 r. ${ }^{71}$ oraz w art. 1, 6-12 oraz 15 Europejskiej Konwencji o wykonywaniu praw dzieci72. Powyższe dokumenty w swej materii opierają się na zapisach przyjętych na forum Narodów Zjednoczonych.

Aktem prawnym Rady Europy o kluczowym znaczeniu dla omawianego zagrożenia jest Konwencja Rady Europy o cyberprzestępczości z dnia 23 listopada 2001 r., w której znalazły się nowe kategorie przestępstw związanych $\mathrm{z}$ produkowaniem, oferowaniem, udostępnianiem, rozpowszechnianiem, transmitowaniem, posiadaniem oraz pozyskiwaniem pornografii dziecięcej za pomocą systemów informatycznych ${ }^{73}$. W art. 9 Konwencja definiuje pornografię dziecięcą jako: „materiał pornograficzny, który w sposób widoczny przedstawia:

- osobę małoletnią w trakcie czynności seksualnej wyraźnie seksualnej;

- osobę, która wydaje się być małoletnia w trakcie czynności wyraźnie seksualnej;

- realistyczny obraz przedstawiający osobę małoletnią w trakcie czynności wyraźnie seksualnej"74.

Konwencja o cyberprzestępczości pojęciem „małoletni” obejmuje wszystkie osoby poniżej 18 roku życia, z tym że Strona może wprowadzić wymóg niższej granicy wieku, ale nie niższej niż lat 16 o czym stanowi art. 9 ust. 3.W art. 11 i 12 Konwencja zobowiązuje Strony do podjęcia środków prawnych i innych jakie okażą się skuteczne dla uznania za przestępstwa $\mathrm{w}$ jej prawie wewnętrznym i zagwarantowania poniesienia odpowiedzialności za popełnienie czynów z art. 2-10, co dotyczy tak osób fizycznych jak i prawnych, a w kolejnych artykułach Konwencja nakłada na Strony obowiązek podjęcia działań w za-

${ }^{71}$ Europejska Konwencja o Ochronie Praw Człowieka i Podstawowych Wolności z 4 listopada 1950 r. (Dz. U. 1993, nr. 61, poz. 284.).

72 Europejska Konwencja o wykonywaniu praw dzieci z dnia 12 grudnia 1996 r. (Dz. U. 2000, nr 107, poz. 1128.).

${ }^{73}$ Konwencja Rady Europy o cyberprzestepczości z dnia 23 listopada 2001 r. (Dz. U. 2015, poz. 728.).

74 Ibidem. 
Mateusz K. Maciejczuk et al. - Cyberprzestępczość a bezpieczeństwo...

kresie określenia sankcji z ww. czyny ${ }^{75}$. Omawiany akt w należy ocenić bardzo pozytywnie, gdyż stanowi on przykład determinacji autorów do ochrony dzieci przed zagrożeniami w cyberprzestrzeni.

Przy analizie dorobku Rady Europy w kontekście omawianego zagadnienia nie sposób pominąć Konwencji Rady Europy z dnia 12 lipca 2007 r. o ochronie dzieci przed seksualnym wykorzystywaniem i niegodziwym traktowaniem w celach seksualnych ${ }^{76}$. Niniejsza Konwencja w sposób szeroki opisuje problematykę bezpieczeństwa dzieci - także w cyberprzestrzeni. W Rozdziale I przedstawianej Konwencji, jako główne cele wymieniono:

- zapobieganie i zwalczanie seksualnego wykorzystania dzieci obcowania z dziećmi;

- ochrona praw dzieci będących ofiarami seksualnego wykorzystywania dzieci i obcowania z dziećmi;

- promowanie krajowej i międzynarodowej współpracy przeciwko seksualnemu wykorzystywaniu dzieci i obcowaniu z dziećmi.

Natomiast w Rozdziale II, Konwencja zwraca szczególną uwagę na rekrutację, szkolenie, podnoszenie świadomości osób mających w swojej pracy kontakt z dziećmi. Ustalenie priorytetów w przedstawiony sposób wskazuje jednoznacznie na położenie głównego nacisku na prewencję i eliminację sytuacji w których istnieje uzasadnione ryzyko, że dzieci zostaną seksualnie wykorzystane lub skrzywdzone w inny sposób ${ }^{77}$.Na szczególną uwagę zasługuje Rozdział VI dotyczący prawa karnego materialnego ${ }^{78}$. Warto podkreślić, iż na potrzeby owej Konwencji z 2007 r. przyjęto nieco inną definicję prostytucji dziecięcej niż w Konwencji z 2001 r., a mianowicie: „termin „dziecięca prostytu-

75 Ibidem.

${ }^{76}$ Konwencja Rady Europy o ochronie dzieci przed seksualnym wykorzystywaniem i niegodziwym traktowaniem $w$ celach seksualnych z dnia 25 października $2007 \mathrm{r}$. (Dz. U. 2015, poz. 608.).

77 P. Jaros, Ochrona dzieci przed seksualnym wykorzystywaniem: nowa Konwencja Rady Europy, „Kwartalnik Prawa Publicznego” 2007, nr 4, s. 81-82.

${ }^{78}$ Konwencja Rady Europy o ochronie dzieci przed seksualnym wykorzystywaniem i niegodziwym traktowaniem $w$ celach seksualnych z dnia 25 października 2007 r. (Dz. U. 2015, poz. 608.). 
cja" oznacza fakt wykorzystania dziecka do czynności seksualnych w sytuacji, gdy zostały przekazane lub obiecane tytułem zapłaty pieniądze lub każda inna forma wynagrodzenia lub świadczenia, bez względu na to, czy tę zapłatę, obietnicę czy świadczenie otrzymało dziecko czy też osoba trzecia”. Nie ograniczono zatem tego terminu do fizycznego działania, a więc można je interpretować w kontekście cyberprzestrzeni. Niewątpliwie stanowi to uzupełnienie postanowień Konwencji o Cyberprzestępczości z 2001 r.

Pomimo tego, iż Konwencje są dokumentami fakultatywnymi to ich doniosłość normatywna stanowi poważny impuls skierowany do władz państw. Oprócz tego dla omawianej problematyki niesprawcze znaczenie mają także rekomendacje i zalecenia Rady Europy i warto je przywołać ze względu na rozwiązania jakie proponują, gdyż mogłoby to znacząco podnieść poziom bezpieczeństwa „mieszkańców” cyberprzestrzeni79. Rekomendacja Komitetu Ministrów Rady Europy Rec (2001)8 dotycząca samoregulacji w zakresie cyberzawartości: samoregulacja oraz ochrona użytkowników przed treściami nielegalnymi i szkodliwymi w usługach informacyjno-komunikacyjnych ${ }^{80}$ określa, iż rola państw członkowskich jest zachęcanie dostawców treści i usług internetowych do tworzenia wraz z użytkownikami organizacji ich reprezentujących oraz tworzenia szerokiej gamy narzędzi pełniących rolę wyszukiwarek i filtrów umożliwiającym internautom selekcję treści, a także stosowanie mechanizmów weryfikacyjnych (wiek, hasła, systemy kodowania itp.) chroniących osoby małoletnie81. Zalecenie Rady Europy CM/Rec (2009)5 z 8 lipca 2009 r. w sprawie ochrony dzieci przed szkodliwymi treściami i zachowaniami oraz promowania ich aktywnego uczestnictwa w nowym środowisku informacyjnym i komunikacyjnym w swej treści rekomenduje współpracę

${ }^{79}$ M. Gruchoła, Ochrona użytkowników Internetu w państwach Unii Europejskiej, Lublin 2012, s. 93.

80 Krajowa Rada Radiofonii i Telewizji, Informacja na temat działań społeczności międzynarodowej na rzecz obcięcia Internetu systemem prawa przy jednoczesnej ochronie swobody wypowiedzi i informacji, Warszawa 2005, s. 28-29.

81 Szerzej: M. Gruchoła, Ochrona użytkowników ..., op. cit., s. 94-95. 
Mateusz K. Maciejczuk et al. - Cyberprzestępczość a bezpieczeństwo...

państw z sektorem prywatnym i organizacjami społecznymi w celu przyjęcia i realizowania spójnej strategii ochrony dzieci wobec internetowych zagrożeń poprzez korzystanie z tzw. bezpiecznych przestrzeni (walledgardens) oraz innych narzędzi zapewniających bezpieczne korzystanie z cyberprzestrzeni dla dzieci82. Należy zgodzić się ze stanowiskiem M. Gruchoły, która twierdzi, iż: „rekomendacje pełnią rolę instrumentów politycznych (wskazują polityczne zaangażowanie państw członkowskich), a nie prawnych (nie mają mocy prawnej), są skierowane do rządów państw członkowskich, którym wskazują konkretne cele do osiągnięcia w zakresie przyczynienia się do bezpiecznego korzystania z Internetu, pozostawiając im jednocześnie swobodę w doborze sposobów realizacji zgodnie z krajowymi prawodawstwami i praktykami oraz międzynarodowymi zobowiązaniami i narodową specyfiką"83.

\section{Podsumowanie}

Próba podsumowania powyższych rozważań niesie ze sobą wiele wątków. W pierwszej kolejności należy stwierdzić, iż ilość źródeł prawa dotyczących ochrony dzieci w cyberprzestrzeni jest pokaźna. Nie rzecz jednak w ilości a w jakości ich zawartości. W związku z tym łatwo zauważyć, że w kontekście omawianego tematu pod względem działań i ich efektów przed ONZ prym wiedzie Rada Europy, co jest impulsem do aktualizacji prawnych porządków państw członkowskich. Powstaje zatem pytanie o pozycję ONZ wobec wzmożonej aktywności organizacji europejskich w kontekście podjęcia próby unifikacji prawa dotyczącego bezpieczeństwa dzieci w cyberprzestrzeni na poziomie globalnym. Obecnie Konwencja Rady Europy o cyberprzestępczości jest pierwszym i jedynym aktem międzynarodowego prawa karnego w erze cyberświata, a przez co cieszy się zainteresowanie znacznej części społeczności międzynarodowej i wy-

\footnotetext{
82 Ibidem, s. 95-96.

83 M. Gruchała, Ochrona użytkowników Internetu w prawie i w praktyce Republiki Federalnej Niemiec, „Kwartalnik Prawa Publicznego” 2007, nr 1-2, s. 45.
} 
wiera istotny wpływ na krajowe porządki prawne państw europejskich i pozaeuropejskich ${ }^{84}$. Taki stan rzeczy cementuje silne poparcie dla ww. Konwencji o cyberprzestepczości ze strony USA oraz UE, które na XII Kongresie Sprawiedliwości Karnej w dniach 12-19.04.2010 r. zajęły krytyczne stanowisko wobec inicjatywy podjęcia prac, pod przewodnictwem ONZ, nad nowym traktatem międzynarodowym w dziedzinie zwalczania cyberprzestępczości85. Niezależnie od stanowisk USA i UE istnieje obiektywna potrzeba ujednolicenia standardów ochrony dzieci w cyberprzestrzeni, gdyż określone zachowanie w jednym kraju może być przestępstwem, a w drugim może nie być penalizowane. Stwarza to problemy w zakresie skutecznego ścigania cyberprzestępców.

Kolejnym kryterium oceny powyższych dokumentów jest ich skuteczność. Na oficjalnym portalu internetowym XII Kongresu ONZ w Sprawie Zapobiegania Przestępczości i Promowania Sprawiedliwości Karnej można przeczytać, iż każdego dnia milion osób pada ofiarą cyberprzestępców, a około 431 milionów osób padło ofiarą cyberprzestępstw - to 14 osób dorosłych na sekundę nie wliczając w to dzieci86. Może się zatem wydawać, iż prawo jest zupełnie nieskuteczne. Jedno byłby to wniosek zbyt uproszczony, gdyż trudno o badania i wyliczenia opisujące skalę zjawiska, gdyby w obrocie prawnym nie funkcjonowały ww. akty prawne. Z drugiej strony nawet najlepsze prawo nie jest w stanie uchronić człowieka przed zagrożeniem ze strony drugiego człowieka nawet $w$ realnej rzeczywistości.

\section{Bibliografia:}

Adamski A., Konwencja Rady Europy o cyberprzestępczości i kwestia jej ratyfikacja przez Polskę, [w:] Internet. Ochrona wolności, własności i bezpieczeństwa, G. Szpor (red.), Wyd. C. H. Beck, Warszawa 2011.

\footnotetext{
${ }^{84}$ https://www.itu.int/ITU-D/cyb/cybersecurity/docs/itu-understanding-cyber crime-guide.pdf, [dostęp: 19-06-2017].

85 A. Adamski, Konwencja Rady Europy o cyberprzestępczości ..., op. cit., s. 345.

$86 \mathrm{http}: / /$ www.unic.un.org.pl/przestepczosc2015/39,2698 [dostęp: 20-06-2017].
} 
Mateusz K. Maciejczuk et al. - Cyberprzestępczość a bezpieczeństwo...

Aleksandrowicz T. R., Świat w sieci. Państwa, społeczeństwa, ludzie. W poszukiwaniu nowego paradygmatu bezpieczeństwa narodowego, Wyd. Difin, Warszawa 2014.

Aleksandrowicz T. R., K. Liedel, Społeczeństwo informacyjne - sieć - cyberprzestrzeń. Nowe zagrożenia, [w:] K. Liedel, P. Piasecka, T. R. Aleksandrowicz (red.), Sieciocentryczne bezpieczeństwo, Wyd. Difin, Warszawa 2014.

Bendyk E., Sieciaki, www.polityka.pl (artykuł z dnia 6 stycznia 2009 r.)

Brzeziński M., Kategoria bezpieczeństwa, [w:] S. Sulkowski, M. Brzeziński (red.), Bezpieczeństwo wewnętrzne państwa. Wybrane zagadnienia, Wyd. Elipsa, Warszawa 2009.

Braun-Gałkowska M., Prawo dziecka do poszukiwania i przekazywania informacji (wpływ środków masowego przekazu na dziecko), [w:] Konwencja o prawach dziecka - analiza I wykładnia, T. Smyczyński (red.), Wyd. Ars boni et aequi, Poznań 1999.

Bogdół-Brzezińska A., Gawrycki M. F., Cyberterroryzm i problemy bezpieczeństwa informacyjnego we współczesnym świecie, Wyd. Oficyna Wydawnicza ASPRA-JR, Warszawa 2003.

Czaputowicz J., Bezpieczeństwo międzynarodowe. Współczesne koncepcje, Wyd. PWN, Warszawa 2012.

Castells M., Społeczeństwo sieci, Wyd. PWN, Warszawa 2007.

Deklaracja Praw Dziecka z 20.11.1959 r., http://libr.sejm.gov.pl/tek01/txt/ onz/1959.html, [dostęp: 19-06-2017].

Dunaj B., Słownik współczesnego języka polskiego, Warszawa 2001.

Europejska Karta Społeczna z 18.12.1961 r. (Dz. U. 1999 r. Nr 8, poz. 67 z późn. zm.).

Europejska Konwencja o Ochronie Praw Człowieka i Podstawowych Wolności z 4 listopada 1950 r. (Dz. U. 1993 r., Nr. 61, poz. 284).

Europejska Konwencja o uznawaniu $i$ wykonywaniu orzeczeń dotyczq̨cych pieczy nad dzieckiem oraz o przywracaniu pieczy nad dzieckiem z 20.05. 1980 r. (Dz. U. 1996 r., Nr 31, poz. 134).

Europejska konwencja o wykonywaniu praw dzieci, z 25.01.1996 r. (Dz. U. 2000 r. Nr 107, poz. 1128).

Galewska E., Kotecka S. (red.), X-lecie CBKE. Księga pamiątkowa z okazji 10lecia Centrum Badań Problemów Prawnych i Ekonomicznych Komunikacji Elektronicznej i Studenckiego Koła Naukowego, Warszawa 2012.

Gibbson W., Neuromancer, New York 1989. 
Gruchoła M., Ochrona użytkowników Internetu w państwach Unii Europejskiej, Wyd. KUL, Lublin 2012.

Gruchoła M., Ochrona użytkowników Internetu w prawie i w praktyce Republiki Federalnej Niemiec, „Kwartalnik Prawa Publicznego” 2007, nr 1-2.

Hall J., (red.), Children's Human Rights and Public Schooling in the United States, Sense Publishers, Rotterdam-Boston-Taipei 2013.

http://www.cert.gov.pl/cer/publikacje/polityka-ochrony-cyber/639,Polityka-

Ochrony-Cyberprzestrzeni-Rzeczypospolitej-Polskiej.html [dostęp: 15-062017].

http://www.europarl.europa.eu/meetdocs/2009_2014/documents/join/com _join(2013)0001_/com_join(2013)0001_pl.pdf, [dostęp: 19-06-2017].

http://www.ita.wat.edu.pl/data/ita/7cf74de3e6ce1531322d80719c7968c2.

html?ts=1390808700, [dostęp: 17-06-2017].

https://www.itu.int/ITU-D/cyb/cybersecurity/docs/itu-understanding-cyber crime-guide.pdf, [dostęp: 19-06-2017].

http://www.unic.un.org.pl/przestepczosc2015/39,2698 [dostęp: 20-06-2017]. http://www.britannica.com/EBchecked/topic/410654/Neuromancer, [do-

stęp:15-06-2017]

Informacja na temat działań społeczności międzynarodowej na rzecz obcięcia Internetu systemem prawa przy jednoczesnej ochronie swobody wypowiedzi i informacji, Krajowa Rada Radiofonii i Telewizji, Warszawa 2005.

Jaros P.J., M. Michalak, Prawa dziecka. Dokumenty Organizacji Narodów Zjednoczonych, Wyd. Rzecznika Praw Dziecka, Warszawa 2015.

Jaros P.J., Ochrona dzieci przed seksualnym wykorzystywaniem: nowa Konwencja Rady Europy, „Kwartalnik Prawa Publicznego” 2007, nr 4.

Konwencja o ochronie praw dziecka z 20.11.1989 r. (Dz. U. 1991 r., Nr 120, poz. 526).

Konwencja Rady Europy o cyberprzestępczości z dnia 23 listopada 2001 r. (Dz. U. 2015 poz. 728).

Konwencja Rady Europy o ochronie dzieci przed seksualnym wykorzystywaniem i niegodziwym traktowaniem $w$ celach seksualnych z 12.07.2007 r., https://ms.gov.pl/Data/Files/_public/ppwd/akty_prawne/rada_europy/ -konwe2.pdf, [dostęp: 19-06-2017].

Konwencja w sprawie kontaktów z dziećmi z 15.05.2003 r., ETS nr 192.

IV Konwencja Genewska o ochronie osób cywilnych podczas wojny z 12.08. 1949 r. (Dz. U. z 1956 r. Nr 38, poz. 171 z późn. zm.). 
Mateusz K. Maciejczuk et al. - Cyberprzestępczość a bezpieczeństwo...

Korzeniowski L.F., Podstawy nauk o bezpieczeństwie, Wyd. Difin, Warszawa 2012.

Kosiński J., Paradygmaty cyberprzestępczości, Wyd. Difin, Warszawa 2015.

Liderman K., Analiza wybranych pojęć dokumentu Polityka Ochrony Cyberprzestrzeni Rzeczypospolitej Polskiej, http://www.ita.wat.edu.pl

Łopatka A., Dziecko. Jego prawa człowieka, Polskie Wyd. Prawnicze IURIS, Warszawa 2000.

Madej M., M. Terlikowski (red.), Bezpieczeństwo teleinformatyczne państwa, Wyd. Polski Instytut Spraw Międzynarodowych, Warszawa 2009.

Majchrzak D., Europejska polityka bezpieczeństwa i obrony, [w:] M. KunBuczko, M. Przybysz (red.), Bezpieczeństwo $w$ dobie globalizacji. Prawo i praktyka, Wyd. Wyższa Szkoła Administracji Publicznej im. S. Staszica w Białymstoku, Białystok 2011.

Majer P., W poszukiwaniu uniwersalnej definicji bezpieczeństwa wewnętrznego, „Przegląd Bezpieczeństwa Wewnętrznego” 2012.

Michałowska G., Międzynarodowa ochrona praw dziecka, Wyd. Uniwersytetu Warszawskiego, Warszawa 2016.

Międzynarodowy Pakt Praw Obywatelskich i Politycznych z 19.12.1966 r. (Dz. U. 1977, nr 38, poz. 137).

Międzynarodowy Pakt Praw Społecznych, Gospodarczych i Kulturalnych z 19.12.1966 r. (Dz. U. 1977, nr 38, poz. 169).

Morbitzer J. (red.), Komputer w edukacji, Wyd. Uniwersytetu Pedagogicznego, Kraków 2009.

Ofodile U.E., The Universal Declaration of Human Rights and the African Child Today: Progress Or Problems?, „American University International Law Review" 2010, vol. 2 (5).

Prensky M., Digital Natives, Digital Immigrants, http://www.marcprensky.com/ writing/Prensky\%20-20Digital\%20Natives,\%20Digital\%20Immigrants\% 20-\%20Part1.pdf, [dostęp: 19-06-2017]

Powszechna Deklaracja Praw Człowieka z 10.12.1948 r. http://libr.sejm.gov.pl/ tek01/txt/onz/1948.html, [dostęp: 19-06-2017].

Rudnicki Z., Deklaracja Genewska praw dziecka z 1924 roku, [w:] E. Karska (red.), Prawa dziecka w prawie międzynarodowym, Warszawa 2013.

Skorupska S., Słownik frazeologiczny języka polskiego, Wyd. Wiedza Powszechna, Warszawa 1987.

Słownik terminów z zakresu psychologii dowodzenia i zarządzania, Warszawa 2000. 
Słownik z zakresu bezpieczeństwa MON, Warszawa $1996 \mathrm{r}$.

Stadniczeńko S. L., (red.) Konwencja o prawach dziecka. Wybór zagadnień (artykuły i komentarze, Wyd. Rzecznika Praw Dziecka, Warszawa 2015.

Stańczyk J., Współczesne pojmowanie bezpieczeństwa, Wyd. PAN, Warszawa 1996.

Szymańczak J., Prawny zakaz fizycznego karania dzieci, „Infos” 2009, nr 6(53). Szymczak. M. (red.), Słownik języka polskiego, Wyd. PWN, Warszawa 1978.

Wiśniewski B. (red.), Bezpieczeństwo w teorii i badaniach naukowych, Wyd. Wyższa Szkoła Policji w Szczytnie, Szczytno 2011.

Zięba R, Kategoria bezpieczeństwa w nauce o stosunkach międzynarodowych, [w:] D. B. Bobrov, E. Haliżak, R. Zięba (red.), Bezpieczeństwo narodowe i międzynarodowe u schyłku XX wieku, Wyd. Scholar, Warszawa 1997.

The National Strategy for Cyberspace, February 2003, http://www.hsdl.org/ ?view\&did=1040, [dostęp: 15-06-2017]. 